HIAS-E-8

\title{
Monitoring, cross subsidies, and universal banking
}

\author{
Jay Pil Choi
}

Department of Economics, Michigan State University, East Lansing, MI 48824, USA

Hitotsubashi Institute for Advanced Study, 2-1, Naka, Kunitachi 186 - 8601, Japan

Christodoulos Stefanadis

Department of Finance, University of Piraeus, 80 Karaoli and Dimitriou, Piraeus 18534, Greece

August 2015

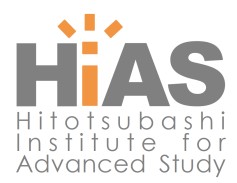

Hitotsubashi Institute for Advanced Study, Hitotsubashi University

2-1, Naka, Kunitachi, Tokyo 186-8601 Japan

tel:+81 $425808604 \quad$ http://hias.ad.hit-u.ac.jp/

HIAS discussion papers can be downloaded without charge from

http://hdl.handle.net/10086/27202

https://ideas.repec.org/s/hit/hiasdp.html

Discussion Papers are not intended for circulation or distribution except as indicated by the author. For that reason Discussion Papers may not be reproduced or distributed without the written consent of the author. 


\title{
Monitoring, Cross Subsidies, and Universal Banking \\ By \\ Jay Pil Choi* \\ Christodoulos Stefanadis**
}

August 2015

\begin{abstract}
We formalize the idea that a financial conglomerate may utilize commercial banking activities to cross-subsidize investment banking through bundled offers. The investment banking sector entails supra-normal profits due to incentive problems with security underwriting. Universal banks may aim to capture (some of) those profits by providing discounts on commercial loans. This practice has an adverse effect on commercial banks' monitoring incentives, encouraging the pursuit of private rents by entrepreneurs. It also leads to lower underwriting fees and a lower probability of successful public offerings. The social welfare effects of universal banking can be either positive or negative.
\end{abstract}

JEL Classification: G21, L10.

Keywords: universal banking, moral hazard, monitoring, cross subsidy, bundled offer.

* Department of Economics, Michigan State University, East Lansing, MI 48824, USA and HIAS, Hitotsubashi University, Japan, choijay@msu.edu

** Department of Finance, University of Piraeus, 80 Karaoli and Dimitriou, Piraeus 18534, Greece, cstefana@unipi.gr

We thank Yongmin Chen, Sung-In Jun, Yongjin Kim and an anonymous referee for helpful suggestions. We are also grateful to participants in the KAEA-Bank of Korea Joint Conferences on Growth Potential and Financial Reform in Korea. The first author gratefully acknowledges the HIAS for financial support and hospitality during his visit there. 
"Did we lend money in hopes of getting lots of other deals? Absolutely..."

-- An anonymous managing director at JP Morgan Chase ${ }^{1}$

\section{INTRODUCTION}

Since the passage of the Gramm-Leach-Bliley Act in the U.S. in 1999, which removed most of the barriers between commercial and investment banking, financial conglomerates have dominated the U.S. investment banking market. This is similar to previous developments in the United Kingdom, where after the legalization of financial conglomerates in 1986, most pure investment banks merged with commercial banks (Smith and Walter (2003)). Some executives comment that commercial lenders often focus on snatching business from investment banks because underwriting activities are more profitable than giving commercial loans (Economist (2002), Association for Finance Professionals (2004)). However, after the onset of the Great Recession in 2008, several economists have also argued that large financial conglomerates, which engage in a broad range of diverse activities, can be socially harmful and may need to be dismantled by the authorities (Johnson and Kwak (2010), Duffie (2010, 2011)). Thus in recent years the mechanics and the social welfare implications of universal banking are an important issue in economics.

This paper presents a theoretical industrial organization model that analyzes the interplay between commercial and investment banking activities and formalizes the popular (among practitioners) idea that a financial conglomerate may engage in commercial banking to strengthen its position in investment banking through bundled offers of financial services. We also study the welfare implications of universal banking. In particular, in the model the investment banking sector is characterized by supra-normal profits that cannot be competed away due to incentive problems inherent in the security underwriting business; excessively low underwriting fees are unacceptable to entrepreneurs because they discourage investment banks from exerting a sufficient effort in underwriting. ${ }^{2}$ We argue that engaging in commercial lending activities through

\footnotetext{
${ }^{1}$ As quoted in Beckett and Sapsford (2002).

${ }^{2}$ Similarly, in labor economics supra-normal "efficiency wages," which are not eroded by competition, are often offered to workers so that workers are provided with incentives to work harder (e.g., Akerlof and Katz (1990), Gächter and Lehmann-Waffenschmidt (2002)).
} 
universal banking provides a cross subsidization channel to secure profits in the investment banking sector. This mechanism provides unilateral incentives to form financial conglomerates if, of course, the legal framework, such as the Gramm-LeachBliley Act in the U.S., allows such conglomerates. However, since in equilibrium all investment banks establish commercial bank divisions, they experience a neutralization of the advantages of a unilateral move toward universal banking and an erosion of (some of) their profits.

We show that commercial banks' equilibrium monitoring incentives in a universal banking system are weaker than in a financial system with functionally separated commercial and investment banks. In particular, since the equilibrium terms of commercial loans are more favorable to entrepreneurs (and less favorable to commercial banks) in a universal banking system, universal banks are less motivated to monitor their borrowers' projects. Borrowers obtain greater private rents in equilibrium, and corporate governance deteriorates. The model also predicts lower underwriting fees and a lower probability of successful underwriting in the investment banking sector under a universal banking regime. This lower probability stems from commercial banks' reduced monitoring incentives under a universal banking regime and from the effects of such reduced monitoring on investment banks' underwriting efforts.

The overall social welfare effects of universal banking stem from the changes in the amount of monitoring. If there is socially insufficient equilibrium monitoring on a local scale in a functionally separated banking system, the universal banking system is welfare-reducing because it exacerbates the inadequacy of monitoring. If, on the other hand, there is socially excessive equilibrium monitoring on a local scale in a universal banking system, the universal banking system is welfare-increasing because it eases the excess of monitoring. Otherwise, the social welfare effects of universal banking are ambiguous.

On the business front, several analysts point out that the use of lending relationships for the advancement of investment banking is often an important part of a universal bank's strategy (Economist (2002), Association for Finance Professionals (2004)). Our paper formalizes this idea by presenting a mechanism for cross subsidies between commercial and investment banking. Our conclusions are consistent with the 
empirical findings of Drucker and Puri (2005) that the joint provision of lending and underwriting services increases a universal bank's probability of obtaining underwriting business, leads to discounted loan yields and decreases underwriting fees for clients. Our analysis also implies that the joint provision of commercial and investment banking services reduces the probability of success of public offerings or of underwriting campaigns. An empirical implication that is unique to our model is that the joint provision of lending and underwriting services leads to an increase in entrepreneurs' private rents and thus to a deterioration of corporate governance in borrowing enterprises. This implication has not been tested in the empirical literature yet.

In the theoretical literature, Kanatas and Qi $(1998,2003)$ examine universal banking in the presence of informational economies of scope. A financial conglomerate incurs a one-time fixed cost to establish a relationship with a client; the client may obtain multiple services from the conglomerate at no additional informational cost. Then, universal banks have weaker incentives to apply costly efforts to a client's underwriting campaign because they know that they will still be able to profitably serve the client's credit needs if the underwriting campaign fails. ${ }^{3}$ Laux and Walz (2009), on the other hand, argue that the effect of universal banking on underwriting can be the opposite. A universal bank may have stronger incentives to apply efforts to underwriting because a failed underwriting campaign may have an adverse effect on the value of the client's outstanding loans that the universal bank has already given. Loranth and Morrison (2012) point out that a universal bank's private decision about whether to offer lending and underwriting services jointly, as well as the socially optimal decision, may be nonmonotonic in the investment banking surplus. Furthermore, more intense investment banking competition may make the joint provision of lending and underwriting services less likely. ${ }^{4}$

Our paper has a different focus from the literature, examining moral hazard and the related monitoring role of commercial banks. Moral hazard stems from the pursuit of private rents by entrepreneurs after financing is obtained. The effects of universal

\footnotetext{
${ }^{3}$ Puri (1999) also examines a universal bank's trade-off between informational economies of scope and conflicts of interest, deriving implications for the prices of underwritten securities.
} 
banking on welfare and the market structure stem from changes in such equilibrium monitoring. Kanatas and Qi (1998, 2003) and Laux and Walz (2009), on the other hand, examine adverse selection (rather than moral hazard) and the related screening role of banks; banks may screen the quality of an entrepreneur's projects before financing is given.

\section{THE MODEL}

Our model contains four classes of agents, namely, an entrepreneur, commercial banks, investment banks and outside investors. All agents are assumed to be risk neutral. An entrepreneur has two consecutive long-term projects, $X$ and $Y$, which need to be funded; he first seeks financing for project $X$ and then, shortly thereafter, for project $Y$. We normalize the upfront cost of projects $X$ and $Y$ to $\$ 1$ and $\$ K$, respectively. The entrepreneur has no funds of his own and thus needs to seek financing from outside sources.

Project financing is subject to moral hazard. In particular, once the long-term projects are funded and initiated, the entrepreneur may seek to abandon the projects and obtain private rents instead, - i.e., a rent $V_{X}$ from project $X$ and a rent $V_{Y}$ from project $Y$, - at the expense of the banks or the outside investors that have financed the projects (in the spirit of Boot and Thakor (1997), Holmstrom and Tirole (1997) and Freixas and Rochet (2008)). If the entrepreneur succeeds in obtaining private rents, both projects yield a payoff of 0 with probability 1 , and thus banks or outside investors obtain a zero payoff (although the entrepreneur obtains a private rent $V_{X}+V_{Y}$ with probability 1). The pursuit of private rents is an entrepreneur-specific, rather than a project-specific, endeavor. Such a pursuit is either successful in all the entrepreneur's activities (i.e., in both projects $X$ and $Y$ ), or unsuccessful across the board.

If the entrepreneur does not obtain private rents, project $X$ is successful and yields a payoff $x$ with probability $\gamma$. With probability $1-\gamma$, on the other hand, the project fails and yields a payoff 0 . Thus, the failure of the project does not constitute foolproof

\footnotetext{
${ }^{4}$ In a different vein, Greenbaum, Kanatas and Venezia (1989), Rajan (1992), Marquez (2002) and Anand and Galetovic (2006), among others, examine the role of long-term client relationships in banking. Barros (1999) focuses on multi-location competition in commercial banking.
} 
evidence of wrongdoing on the part of the entrepreneur. ${ }^{5}$ We assume that the payoff of a project is observable and verifiable. Similarly, if the entrepreneur does not obtain private rents, project $Y$ is successful and yields a payoff $y$ with probability $\lambda$. With probability $1-\lambda$, the project fails and yields a payoff $0 .{ }^{6}$ For simplicity, we assume that the success of project $X$ is independent of the success of project $Y$. However, our results carry through to any level of correlation between projects $X$ and $Y$. We assume that $V_{X}>\gamma x-1$ and $V_{Y}>\lambda y-K$, which implies that the entrepreneur prefers to pursue private rents $V_{X}$ and $V_{Y}$ after he obtains financing. We also assume that $\gamma x>V_{X}$ and $\lambda y>V_{Y}$, which implies that the pursuit of private rents is socially inefficient.

There are two commercial banks, $\mathrm{CB} 1$ and $\mathrm{CB} 2$, which can give loans for a project to the entrepreneur. A loan contract specifies the repayment rate, $r_{B}$, that the entrepreneur is required to pay to the commercial bank after the completion of the project. $^{7}$ However, if the project yields a zero payoff, it inevitably goes bankrupt, and a zero amount is repaid to the bank. Banks are unable to stake a claim to any private rents that the entrepreneur may have obtained. CB1 and CB2 compete in a Bertrand manner in the repayment rate, $r_{B}$, that they offer to the entrepreneur. We assume that an entrepreneur's contract with a commercial bank is publicly observable. Furthermore, as is standard in finance theory, commercial banks are able to engage in monitoring activities that aim to prevent the pursuit of private rents by the entrepreneur. ${ }^{8}$ Monitoring is costly, however. We assume that private rents can be prevented with probability $\theta$ if commercial banks incur a monitoring cost $C_{M}(\theta)$, where $C_{M}(0)=0, C_{M}{ }^{\prime}(\theta)>0$ and $C_{M}{ }^{\prime \prime}(\theta)>0$. Banks' monitoring activities are not contractible because monitoring expenditures are either unobservable or non-verifiable in courts.

\footnotetext{
${ }^{5}$ Our results carry through when project $X$ yields a payoff $x$ with probability $\gamma^{\prime}$ and a payoff 0 with probability $1-\gamma^{\prime}$ when the entrepreneur obtains a private rent, where $\gamma^{\prime}<\gamma$.

${ }^{6}$ Similarly to note 5 , our results carry through when project $Y$ yields a payoff $y$ with probability $\lambda^{\prime}$ and a payoff 0 with probability $1-\lambda^{\prime}$ when the entrepreneur obtains a private rent, where $\lambda^{\prime}<\lambda$.

${ }^{7}$ If, for example, the entrepreneur borrows an amount $z$, he is required to repay an amount $z r_{B}$.

${ }^{8}$ See, for example, Diamond (1984), Besanko and Kanatas (1993) and Freixas and Rochet (2008) for a discussion of the interplay between commercial banking and monitoring.
} 
There are two investment banks, IB1 and IB2, which can assist the entrepreneur in obtaining financing for a project from competitive outside investors. We assume that the success of such capital market financing depends on the investment bank's efforts. In particular, a probability $\alpha$ of a successful public offering can be achieved at a cost $\mathrm{C}_{U}(\alpha)$, where $\mathrm{C}_{U}(0)=0, \mathrm{C}_{U}{ }^{\prime}(\alpha)>0$ and $\mathrm{C}_{U}{ }^{\prime \prime}(\alpha)>0$. For simplicity, it is also assumed that $\mathrm{C}_{U}$ "' $(\alpha)>0$ which, as we will see, is a sufficient (but not necessary) condition for the entrepreneur's profit from a project to be a concave function of the underwriting fee. ${ }^{9}$ An investment bank's effort, $\alpha$, is not contractible. If the public offering is successful, the entrepreneur obtains financing (via the assistance of the investment bank) from the outside investors that require the lowest repayment rate, $r_{I}$, for their funds. If, on the other hand, the public offering fails (and given that the entrepreneur has chosen to obtain financing from outside investors, rather than from a commercial bank), the project is not implemented. ${ }^{10}$

An investment bank charges an underwriting fee, $\mu$. As in Kanatas and Qi (2003) and Laux and Walz (2009) (and as is often the case in practice), the entrepreneur is required to pay $\mu$ only if the public offering is successful. Thus with the upfront cost of a project being, for example, $z$ and the underwriting fee being $\mu$, the amount of funding for the project that the entrepreneur needs to obtain from outside investors is $z+\mu$. IB1 and IB2 compete in a Bertrand manner in the underwriting fee, $\mu$, that they offer to the entrepreneur. For incentive compatibility reasons, we assume that investment banks can compete only in terms of $\mu$. They are unable, for example, to offer up-front lump-sum cash payments to the entrepreneur in an attempt to secure underwriting business. In particular, if such up-front cash payments were utilized, the entrepreneur could have an incentive to obstruct successful public offerings in an attempt to pocket the up-front cash payments from the investment bank and possibly repeat the public offering (and obtain additional up-front cash payments from investment banks) in the future. ${ }^{11}$

\footnotetext{
${ }^{9}$ Many standard cost functions meet this condition.

${ }^{10}$ Our results would be similar if in case of a public offering failure, the entrepreneur could still finance the project (e.g., from commercial banks), but at an increased cost (e.g., because of the delay).

${ }^{11}$ For example, contract incompleteness would impede (or make very costly) the efforts of an investment bank to protect itself against such perverse incentives on the part of the entrepreneur if up-front cash
} 
Investment banks do not have the capability to monitor entrepreneurs. In particular, as is well-known, in practice investment banks usually do not provide their own funds to entrepreneurs; they merely assist entrepreneurs in obtaining financing from outside investors and give their seal of approval to such outside financing (Brealey and Myers (2003)). Thus since investment banks are usually not involved in entrepreneur projects in the long run (but only in the very short run), they are indifferent to the entrepreneur's subsequent moral hazard problem, - which occurs after financing is obtained, - and do not develop any monitoring capabilities. We also make the standard assumption that outside investors lack monitoring capabilities. For example, the small size of each outside investor's stake in a project may be too small to justify private monitoring (Diamond (1984), Freixas and Rochet (2008)). Overall, in the spirit of the delegated monitoring theory of financial intermediation, we assume that only commercial banks have the ability to monitor entrepreneurs; in this way, commercial bank loans are "unique" (e.g., Diamond (1984), Besanko and Kanatas (1993), Freixas and Rochet (2008)). ${ }^{12}$

In the model at least one project needs to be financed by commercial banks for a strictly positive amount of monitoring to occur (since only commercial banks have monitoring capabilities). As, for example, in Laux and Walz (2009) and Loranth and Morrison (2012), we assume that the entrepreneur seeks financing from commercial banks for project $X$ and from outside investors (via investment banks' underwriting) for subsequent project $Y$. This is in the spirit of Fama (1985), Diamond (1991), Rajan (1992) and Freixas and Rochet (2008), among others, who imply that entrepreneurs may tend to rely more on financing from commercial banks in their earlier projects. ${ }^{13}$

payments were utilized. A similar problem that has been studied extensively in labor economics concerns "efficiency wages." Firms often offer workers supra-normal "efficiency wages" so that workers are provided with incentives to work harder. However, in practice, workers usually do not pay (and neither are required by firms to pay) any up-front entrance fees into the job to gain access to such supra-normal "efficiency wages" (although up-front fees would not affect their subsequent incentives to work hard); supra-normal wage rents are not eroded by competition among workers (e.g., Akerlof and Katz (1990), Gächter and Lehmann-Waffenschmidt (2002)).

${ }^{12}$ For example, when the development of monitoring capabilities entails scale economies, commercial banks have a comparative advantage since a commercial bank typically finances many projects (Freixas and Rochet (2008)).

${ }^{13}$ Our results carry through even if there is investment banking activity prior to a commercial loan as long as there is also investment banking activity subsequent to the commercial loan. 
We have a five-stage game that is summarized in figure 1. Given the long-term nature of projects, monitoring by commercial banks occurs after the end of the entrepreneur's financing campaign. Financing merely signifies the start of a project while monitoring affects a project's long-term implementation.

FINANCING

IMPLEMENTATION

COMPLETION

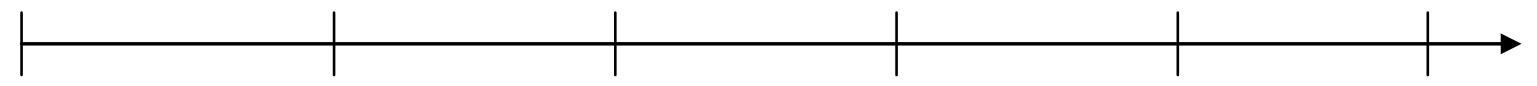

\begin{tabular}{|l|}
\hline Stage 1: \\
Commercial \\
banks CB1 \\
and CB2 \\
compete for \\
the financing \\
of project $X$.
\end{tabular}

Stage 2:

Investment banks IB1

and IB2

compete to

provide

underwriting

services for

project $Y$.
Stage 3: The

investment

bank that

prevailed at

stage 2

chooses its

effort level

$\alpha$. Nature

determines

accordingly

whether the

public

offering

succeeds or

fails.

Stage 4: The
commercial
bank that
prevailed at
stage 1
chooses its
monitoring
level $\theta$.
Nature
determines
accordingly
whether the
pursuit of
private rents
by the
entrepreneur
succeeds or
fails.

Stage 5:

Projects are completed. If payoffs are not zero, commercial banks and outside investors are repaid.

Figure 1: The Timeline for the Game

We adopt the standard tie-breaking convention that when the entrepreneur is indifferent between the offers of the two commercial banks, CB1 and CB2, at stage 1, or between the offers of the two investment banks, IB1 and IB2, at stage 2, he randomly chooses between the two tied offers, picking each offer with probability 0.5. Furthermore, if a universal bank is present, - i.e., if CB1 has merged with IB1 and/or $\mathrm{CB} 2$ has merged with IB2, - the universal bank may make a stage 1 bundled offer that is contingent upon a commitment (by the entrepreneur) to obtain underwriting business at stage 2. In such a bundled offer there is a very simple form of commitment on the part of the entrepreneur. In particular, at stage 1 the entrepreneur may simply commit to show 
preference to a universal bank at stage 2 in case there is a tie between the universal bank's offer and competing offers at stage 2, i.e., if the universal bank's stage 2 offer is not worse than competing offers. ${ }^{14}$ This simple form of bundled offers is consistent with the casual observation that in practice universal banks may give loans merely in implicit "hopes" of, rather than under an explicit contract for, obtaining future underwriting business (see, for example, note 1); it is also compatible with various legal restrictions in some countries. $^{15}$

\section{EQUILIBRIUM IN A FUNCTIONALLY SEPARATED BANKING SYSTEM}

In this section we examine a functionally separated banking system, in which commercial banks, CB1 and CB2, and investment banks, IB1 and IB2, are independent entities. To solve for the equilibrium we proceed by backward induction. Let $r_{B}$ be the repayment rate that the entrepreneur has agreed (at stage 1) to pay to a commercial bank in exchange for obtaining financing, $\$ 1$, for project $X$. At stage 4 , the commercial bank chooses a monitoring level $\mathscr{\theta} r_{B}$ ) according to the following maximization problem: ${ }^{16}$

$$
\left.\mathscr{\theta} r_{B}\right)=\underset{\theta}{\arg \max }\left\{\theta \gamma r_{B}-{ }_{\mathrm{M}} \theta\right.
$$

The commercial bank faces a trade-off between the payoff $r_{B}$ that it will obtain with probability $\gamma$ (i.e., in case project $X$ is successful) if the generation of private rents is prevented and the monitoring cost $\mathrm{C}_{\mathrm{M}}(\theta)$ that it incurs to prevent the generation of private rents. The first-order condition is $\gamma r_{B}$ 쟆 $^{\prime}\left({ }_{M}\right) \theta \theta$. By totally differentiating the first order condition, we can easily verify that the monitoring level is increasing in $r_{B}$ :

\footnotetext{
${ }^{14}$ Such a simple agreement is consistent with the notion that the entrepreneur may agree to show preference to the universal bank as his provider of underwriting services in the future as long as the underwriting terms that the universal bank will offer will not be too unfavorable compared with competing offers.

${ }^{15}$ For example, in the U.S. an explicit contract in bundled offers may be illegal. Furthermore, according to sections 23A and 23B of the Federal Reserve Act, national banks are not allowed to charge interest rates on their loans that are below market to benefit or cross-subsidize investment banking affiliates. The form of bundled offers in our model is consistent with such restrictions.

${ }^{16}$ Since (1) is continuous and strictly concave on $\theta \in[0,1]$, it has a unique argument of the maximum on $\theta \in[0,1]$.
} 


$$
\frac{d \theta\left(r_{B}\right)}{d r_{B}}=\gamma\left[\frac{d^{2} C_{M}(\theta)}{d \theta^{2}}\right]^{-1}>0 .
$$

A higher repayment rate $r_{B}$ encourages the commercial bank to apply greater monitoring $\theta$ to the entrepreneur so that it can have a higher probability $\theta \gamma$ of actually obtaining this repayment rate.

Let $\mu$ be the underwriting fee that the entrepreneur has agreed (at stage 2) to pay to an investment bank in exchange for a successful public offering. At stage 3, the investment bank chooses its effort $2 x \mu$ ) according to the following maximization problem: ${ }^{17}$

$$
\chi \alpha \mu)=\underset{\alpha}{\arg \max }\left\{\alpha \mu-\mathrm{C}_{U}(\alpha)\right\}
$$

The investment bank faces a trade-off between the fee $\mu$ that it will obtain if the underwriting campaign is successful and the cost $\mathrm{C}_{U}(\alpha)$ of such a campaign. The firstorder condition is $\mu-\mathrm{C}_{U}{ }^{\prime}(\alpha)=0$. By totally differentiating the first-order condition, we can see that $d \alpha(\mu) / d \mu=1 / C_{U} "(\alpha)>0$.

In case the public offering is successful at stage 3, competitive outside investors (who earn a zero expected profit) require a repayment rate $r_{I}$ that is equal to $1 /\left[\theta\left(r_{B}\right) \lambda\right]$ (and thus a repayment amount that is equal to $\left.(K+\mu) /\left[\theta\left(r_{B}\right) \lambda\right]\right)$ in exchange for providing an amount $K+\mu$ to the entrepreneur. Outside investors anticipate that the entrepreneur has a probability $\theta\left(r_{B}\right) \lambda$ of repaying the amount $(K+\mu) /\left[\theta\left(r_{B}\right) \lambda\right]$.

\footnotetext{
${ }^{17}$ Since (3) is continuous and strictly concave on $\alpha \in[0,1]$, it has a unique argument of the maximum on $\alpha \in[0,1]$.
} 
At stage 2 Bertrand competition between investment banks IB1 and IB2 drives the underwriting fee to the level $\mu\left(r_{B}\right)$ that maximizes the entrepreneur's expected payoff from project $Y .^{18}$

$$
\left.\mu r_{B}\right)=\underset{\mu}{\arg \max }\left\{\alpha(\mu)\left[\theta\left(r_{B}\right) \lambda y-(K+\mu)+\left(1-\theta\left(r_{B}\right)\right) V_{Y}\right]\right\} .
$$

The first-order condition of (4) is

$$
\frac{d \alpha(\mu)}{d \mu}\left[\theta\left(r_{B}\right) \lambda y-(K+\mu)+\left(1-\theta\left(r_{B}\right)\right) V_{Y}\right]-\alpha(\mu)=0
$$

A larger underwriting fee encourages the investment bank to apply a greater effort, but also implies a larger payment on the part of the entrepreneur. The optimal level, $\mu\left(r_{B}\right)$, of the underwriting fee incorporates those two opposing effects. Thus in the stage 2 subgame equilibrium the entrepreneur's expected profit from project $Y$ is $\Pi_{E}^{Y}\left(r_{B}\right)=\alpha\left(\mu\left(r_{B}\right)\right)\left[\theta\left(r_{B}\right) \lambda y-\left(K+\mu\left(r_{B}\right)\right)+\left(1-\theta\left(r_{B}\right)\right) V_{Y}\right]$. By applying condition (5) to this expression, we can also see that $\left.\mathrm{PT}_{E}^{Y} r_{B}\right)=\alpha\left(\mu\left(r_{B}\right)\right)^{2} / \alpha^{\prime}\left(\mu\left(r_{B}\right)\right)$.

Thus at stage 2 both investment banks, IB1 and IB2, offer an underwriting free $\mu\left(r_{B}\right)$ to the entrepreneur and have an equal probability, 0.5 , of being chosen by the entrepreneur. Condition (3) implies that in interior solutions, the chosen investment bank earns a strictly positive (or a supra-normal) expected profit, $\Pi_{I B}\left(r_{B}\right)=\alpha\left(\mu\left(r_{B}\right)\right) \mu\left(r_{B}\right)-\mathrm{C}_{U}\left(\alpha\left(\mu\left(r_{B}\right)\right)\right)>0 ;$ similarly, before the choice of the entrepreneur is made, each investment bank has a strictly positive expected profit, $0.5 \Pi_{I B}\left(r_{B}\right)>0 .{ }^{19}$ Bertrand competition among investment banks (which offer homogeneous services) cannot erode such a strictly positive profit because the

\footnotetext{
${ }^{18}$ (4) is continuous and strictly concave (since $\left.C_{U}{ }^{\prime \prime}(\alpha)>0\right)$ on $\mu \in\left[0, \theta\left(r_{B}\right) \lambda y+\left(1-\theta\left(r_{B}\right)\right) V_{Y}-K\right]$ and thus has a unique argument of the maximum on $\mu \in\left[0, \theta\left(r_{B}\right) \lambda y+\left(1-\theta\left(r_{B}\right)\right) V_{Y}-K\right]$. We can see that the entrepreneur will never offer an underwriting fee $\mu$ that is strictly larger than $\theta\left(r_{B}\right) \lambda y+\left(1-\theta\left(r_{B}\right)\right) V_{Y}-K$ since in this case the entrepreneur's expected payoff would be strictly negative.
} 
entrepreneur is unwilling to accept an underwriting fee strictly lower than $\mu\left(r_{B}\right)$. In practice, it is well-known that investment banking is considerably more lucrative than commercial banking (Hayes and Spence (1983), Pugel and White (1985), Rajan (1996)). ${ }^{20}$ Our model thus provides a possible explanation, - i.e., the presence of inherent incentive problems with securities underwriting, - for the persistence of supranormal profits in the investment banking sector. ${ }^{21}$

Lemma 1: Each investment bank earns a strictly positive expected profit $0.5 \Pi_{I B}\left(r_{B}\right)>0$.

Proof: It follows from the discussion above.

We can see that the underwriting fee, $\mu\left(r_{B}\right)$, in the stage 2 subgame equilibrium is increasing in the repayment rate, $r_{B}$, that was specified in the entrepreneur's loan contract at stage 1, i.e., $d \mu\left(r_{B}\right) / d r_{B}>0$. Furthermore, the investment bank's expected profit, as well as the entrepreneur's expected profit from project $Y$, is increasing in $r_{B}$, i.e., $d \Pi_{I B}\left(r_{B}\right) / d r_{B}>0$ and $d \Pi_{E}^{Y}\left(r_{B}\right) / d r_{B}>0$. We summarize in lemma 2 .

Lemma 2: A higher repayment rate, $r_{B}$, in project $X$ subsequently leads to a larger underwriting fee in project $Y$ and to greater expected profits from project $Y$ for the investment bank and the entrepreneur, i.e., $d \mu\left(r_{B}\right) / d r_{B}>0, d \Pi_{I B}\left(r_{B}\right) / d r_{B}>0$ and $d \Pi_{E}^{Y}\left(r_{B}\right) / d r_{B}>0$.

Proof: The proof is in the appendix.

\footnotetext{
${ }^{19}$ For very low levels of $\mu\left(r_{B}\right)$, it may be possible (if $\mu\left(r_{B}\right)<C_{U}{ }^{\prime}(0)$ ) to have a corner solution in which the investment bank exerts a zero effort and earns a zero profit. We focus on interior solutions.

${ }^{20}$ Rajan (1996), for example, points out that "the important question that is often left unasked is why these alleged excess profits exist in investment banking."

${ }^{21}$ Similarly, in labor economics companies often offer supra-normal "efficiency wages" to their employees to provide them with incentives to work harder. See notes 2 and 11.
} 
Intuitively, a higher repayment rate, $r_{B}$, in project $X$ increases the level of monitoring, $\theta$, that the commercial bank applies to the entrepreneur (condition (2)). Furthermore, before the entrepreneur obtains financing for project $Y$, he anticipates that the successful financing of $Y$ will generate an expected profit, $\theta\left(r_{B}\right) \lambda y-(K+\mu)+\left(1-\theta\left(r_{B}\right)\right) V_{Y}$, that is increasing in the level, $\theta\left(r_{B}\right)$, of monitoring. ${ }^{22}$ In particular, competitive outside investors in project $Y$ always incorporate into the repayment rate, $r_{I}=1 /\left[\theta\left(r_{B}\right) \lambda\right]$, the risk of private rent-seeking by the entrepreneur so that the expected repayment amount, $K+\mu$, is constant. The entrepreneur's expected revenue, on the other hand, is increasing in the level of monitoring since private rentseeking is socially inefficient and decreases expected revenues $\left(\lambda y>V_{Y}\right)$. Then, such an increase in expected profits that results from more monitoring encourages the entrepreneur to offer a larger underwriting fee to investment banks so that the latter can apply a greater underwriting effort and the probability of successful financing can increase. Investment banking thus becomes more lucrative when monitoring increases.

At stage 1 a commercial bank's expected profit, $\Pi_{C B}\left(r_{B}\right)=\theta\left(r_{B}\right) \gamma r_{B}-C_{M}\left(\theta\left(r_{B}\right)\right)-1$, is an increasing function of the repayment rate $r_{B}$ that the bank secures, i.e., $d \Pi_{C B}\left(r_{B}\right) / d r_{B}>0$. There is a thus unique rate $\overline{r_{B}}\left(\overline{r_{B}}>1 / \gamma\right)$ so that $\Pi_{C B}\left(\overline{r_{B}}\right)=0 .{ }^{23}$ A commercial bank will never offer a repayment rate strictly lower than $\overline{r_{B}}$ since it would then have a strictly negative expected profit. Then, at stage 1 Bertrand competition between commercial banks $\mathrm{CB} 1$ and $\mathrm{CB} 2$ drives the repayment rate on project $X$ to a level $r_{B} \geq \overline{r_{B}}$ that maximizes the entrepreneur's expected payoff (from both projects $X$ and $Y$ ), $\Pi_{E}\left(r_{B}\right)=\theta\left(r_{B}\right) \gamma\left(x-r_{B}\right)+\left[1-\theta\left(r_{B}\right)\right] V_{X}+\Pi_{E}^{Y}\left(r_{B}\right) .^{24}$

\footnotetext{
${ }^{22}$ Of course, as we explained in section 2, after the entrepreneur obtains financing, he prefers to pursue private rents $\left(V_{Y}>\lambda y-K\right)$.

${ }^{23}$ An application of the envelope theorem to condition (1) implies that $d \Pi_{C B}\left(r_{B}\right) / d r_{B}=\theta\left(r_{B}\right) \gamma>0$. We can see that $\Pi_{C B}(1 / \gamma)=\theta(1 / \gamma)-C_{M}(\theta(1 / \gamma))-1<0$ and $\lim _{r_{B} \rightarrow \infty} \Pi_{C B}\left(r_{B}\right)=\infty$. There thus exists a unique $\overline{r_{B}}>1 / \gamma$ so that $\Pi_{C B}\left(\overline{r_{B}}\right)=0$.

${ }^{24}$ Notice that a lower repayment rate $r_{B}$ in project $X$ is not always desirable for the entrepreneurs since $r_{B}$ (and the resulting level of monitoring by the commercial bank) also affects the entrepreneur's expected payoff in subsequent project $Y$. The entrepreneur aims to maximize his overall payoff.
} 
To bring out the effects of universal banking in a straightforward manner, we assume that $\Pi_{E}\left(r_{B}\right)$ is strictly decreasing in $r_{B}$ for all $r_{B} \geq 1 / \gamma$.

$$
\frac{d \Pi_{E}\left(r_{B}\right)}{d r_{B}}=\frac{d \theta\left(r_{B}\right)}{d r_{B}}\left[\gamma\left(x-r_{B}\right)-V_{X}\right]-\theta\left(r_{B}\right) \gamma+\frac{d \Pi_{E}^{Y}\left(r_{B}\right)}{d r_{B}}<0, \forall r_{B} \geq 1 / \gamma
$$

Thus the entrepreneur is better off when commercial banks offer lower repayment rates in project $X$; the entrepreneur always prefers to borrow for project $X$ at the lowest possible repayment rate. ${ }^{25}$

At stage 1 competition between commercial banks CB1 and CB2 leads to an equilibrium repayment rate $\overline{r_{B}}$, i.e., to the lowest repayment rate that allows commercial banks to earn non-negative expected profits. Then, the entrepreneur's equilibrium expected profit is $\Pi_{E}\left(\overline{r_{B}}\right)$, and the commercial bank's expected profit is zero, i.e., $\Pi_{C B}\left(\overline{r_{B}}\right)=0$. The equilibrium underwriting fee is $\mu\left(\overline{r_{B}}\right)$ while each investment bank's equilibrium expected profit is $0.5 \Pi_{I B}\left(\overline{r_{B}}\right)$ (since each investment bank has a probability of 0.5 of being chosen as the underwriter at stage 2). We summarize in lemma 3 (which, as we explained, stems from assumption (6)).

Lemma 3: $\mathrm{CB} 1$ or CB2 finances project $X$ with an equilibrium repayment rate $\overline{r_{B}}$ and earns a zero profit. Each of IB1 and IB2 has a equal probability 0.5 of becoming the underwriter and thus has an equilibrium expected profit of $0.5 \Pi_{I B}\left(\overline{r_{B}}\right)>0$.

Proof: It directly follows from the discussion above.

\section{EQUILIBRIUM IN A UNIVERSAL BANKING SYSTEM}

In this section we examine universal banking systems. We first suppose that commercial bank $\mathrm{CB} 1$ and investment bank IB1 constitute a single entity, namely universal bank UB1, while CB2 and IB2 are independent entities. Thus at stage 1 UB1

\footnotetext{
${ }^{25}$ If, on the other hand, condition (6) does not hold, universal banking may not generate any effects.
} 
can make bundled offers, jointly offering commercial banking and underwriting services; as explained in section 2, UB1's repayment rate in project $X$ is offered jointly with an agreement that UB1 will be the preferred provider of underwriting services at stage 2 in case UB1 and IB2 make similar underwriting offers (and the entrepreneur is otherwise indifferent between the two).

We saw in section 3 that the lowest repayment rate in project $X$ that $\mathrm{CB} 2$ is able to offer is $\overline{r_{B}}$. Then, UB1 can undercut $\mathrm{CB} 2$ by offering a rate $\overline{r_{B}}-\varepsilon$, where $\varepsilon$ is infinitesimal. As is standard, in technical terms such undercutting can be expressed through the assumption that in case of a tie the entrepreneur chooses to borrow from a universal bank at stage 1; UB1 thus offers a rate $\overline{r_{B}}$ and finances project $X$. At stage 2 UB1 becomes the entrepreneur's underwriter by offering an underwriting fee $\mu\left(\overline{r_{B}}\right),-$ the same as IB2's offer, - and by being chosen according to the terms of UB1's bundled stage 1 offer. It follows that the bundled offer of commercial banking and underwriting services allows $\mathrm{CB} 1$ to earn an expected profit $\Pi_{I B}\left(\overline{r_{B}}\right)$ from investment banking as compared to $\Pi_{I B}\left(\overline{r_{B}}\right) / 2$ if CB1 and IB1 were independent entities (in which case IB1 would only have a probability 0.5 of becoming the underwriter). We summarize in lemma 4.

Lemma 4: In the presence of a universal bank, UB1, and of two independent entities, CB2 and IB2, UB1 makes a bundled offer of commercial and investment banking services and finances project $X$ with an equilibrium repayment rate $\overline{r_{B}}$. UB1 always becomes the underwriter of project $Y$ and earns an equilibrium expected profit of $\Pi_{I B}\left(\overline{r_{B}}\right)>0$.

Proof: It directly follows from the discussion above. 
Intuitively, a universal bank makes bundled offers of commercial and investment banking services. ${ }^{26}$ As we have explained, incentive problems with the process of underwriting, - the entrepreneur's need to encourage the investment bank to apply the appropriate effort to the underwriting process, - prevent the underwriting fee from falling below $\mu\left(r_{B}\right)$; a financial institution is thus prevented from competing for the supra-normal investment banking profits by offering lower underwriting fees. A universal bank may then offer discounts on commercial banking services (even if such discounts only need to be infinitesimal in case there is only universal bank on the financial market) to obtain lucrative underwriting business; in bundled offers commercial banking cross-subsidizes underwriting. ${ }^{27}$

An independent investment bank is unable to compete with universal banks since, as we have explained, incentive compatibility reasons prevent the utilization of up-front cash payments by an investment bank to the entrepreneur to secure subsequent lucrative underwriting business. Such up-front cash payments would distort the entrepreneur's incentives, possibly encouraging him to obstruct successful public offerings and repeat the public offering process in the future to pocket additional up-front cash payments from investment banks (also see note 11). However, a universal bank that offers a discount on a loan (rather than up-front cash payments) to secure lucrative underwriting business does not face a similar incentive compatibility problem. Since the loan is largely a major onetime arrangement that (unlike up-front cash payments) cannot be (easily) repeated in the future, the entrepreneur does not have any incentive to obstruct the public offering in hopes of further future gains.

We now suppose that commercial bank CB2 and investment bank IB2 also constitute universal bank UB2; there are two universal banks, UB1 and UB2, in the financial market. We can see that when a universal bank makes a bundled offer of commercial and investment banking services, it has an expected profit,

\footnotetext{
${ }^{26}$ Such bundled offers of commercial and investment banking services are rather common in practice (Economist (2002), Association for Finance Professionals (2004)).

${ }^{27}$ Lemma 4 is consistent with the empirical findings of Drucker and Puri (2005) that the joint provision of commercial and investment banking services increases the financial institution's probability of obtaining underwriting business and also leads to discounted commercial loan yields.
} 
$\Pi_{C B}\left(r_{B}\right)+\Pi_{I B}\left(r_{B}\right)$, that is increasing in $r_{B}{ }^{28}$ We also have $\Pi_{C B}\left(\overline{r_{B}}\right)+\Pi_{I B}\left(\overline{r_{B}}\right)>0$. There thus exists a unique $r_{B} \in\left[0, \overline{r_{B}}\right)$ so that $\Pi_{C B}\left(r_{B}\right)+\Pi_{I B}\left(r_{B}\right)=0 .{ }^{29}$ The lowest repayment rate in project $X$ that a universal bank is able to offer is $r_{B}$; if $r_{B}<r_{B}$, the universal bank earns a strictly negative profit. Furthermore, in section 3 we explained that a larger $r_{B}$ has opposing effects, - i.e., both positive and negative effects, - on $\Pi_{E}\left(r_{B}\right)$. Let $r_{B}=\underset{r_{B} \in\left[r_{B}, r_{B}\right]}{\arg \max } \Pi_{E}\left(r_{B}\right){ }^{30}$ It follows that competition between CB1 and CB2 drives the repayment rate of project $X$ to $\underline{r_{B}}=\max \left\{r_{B}, r_{B}\right\}$, i.e., the entrepreneur's most preferred rate subject to a universal bank's non-negative profit constraint.

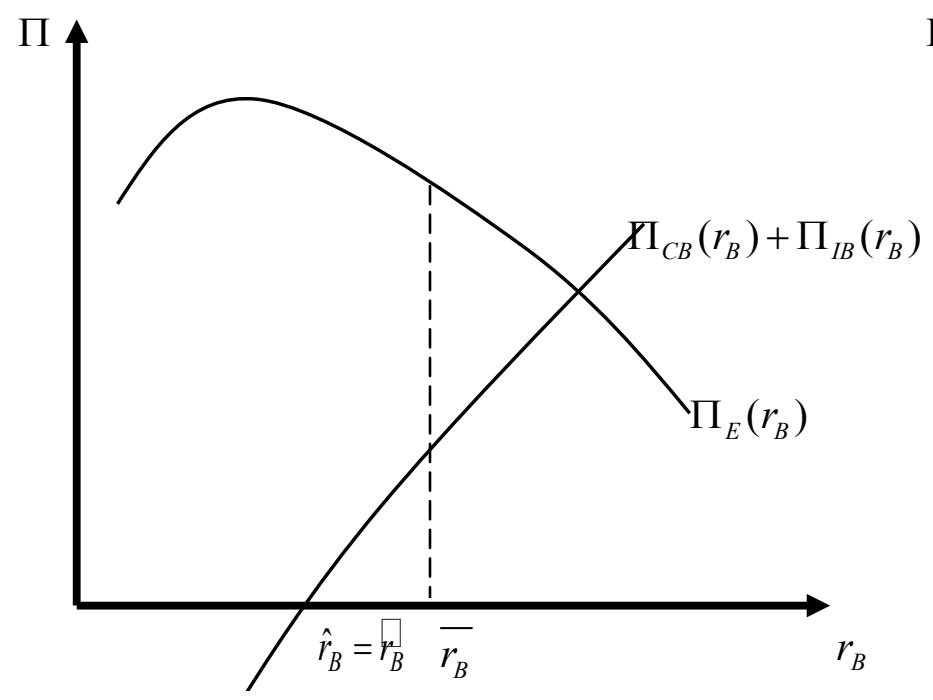

CASE I: $\underline{r_{B}}=r_{B}=r_{B}$

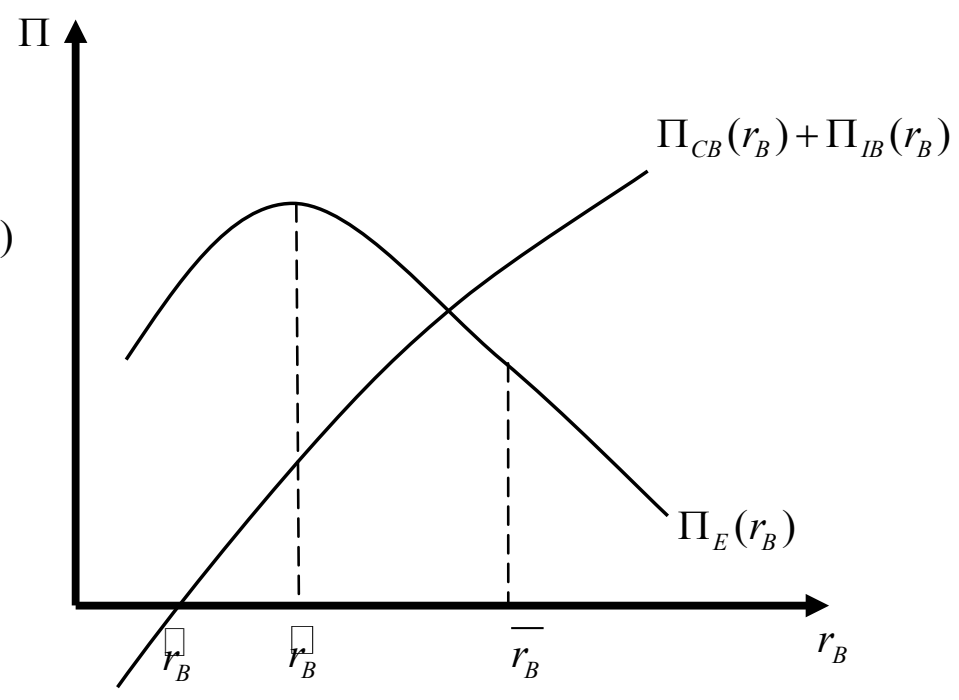

CASE II: $\underline{r_{B}}=r_{B}>r_{B}$

Figure 2: Equilibrium Commercial Loan Rates under Universal Banking

${ }^{28}$ An application of the envelope theorem to condition (1) implies that $d \Pi_{C B}\left(r_{B}\right) / d r_{B}=\theta\left(r_{B}\right) \gamma>0$. Furthermore, lemma 2 and an application of the envelope theorem to condition (3) imply that $d \Pi_{I B}\left(r_{B}\right) / d r_{B}=\left[d \Pi_{I B}(\mu) / d \mu\right]\left(d \mu / d r_{B}\right)=\alpha(\mu) \mathrm{d} \mu\left(r_{B}\right) / \mathrm{dr}_{B}>0$.

${ }^{29}$ If $\Pi_{C B}(0)+\Pi_{I B}(0)>0$, we have a corner solution in which $r_{B}=0$ and $\Pi_{C B}\left(r_{B}\right)+\Pi_{I B}\left(r_{B}\right)>0$.

${ }^{30}$ According to assumption (6), $d \Pi_{E}\left(r_{B}\right) / d r_{B}<0, \forall r_{B} \geq 1 / \gamma$. However, this is not necessarily the case when $r_{B}<1 / \gamma$. 
In terms of a universal bank's expected profit, there are two possible cases (see figure 2). If $\underline{r_{B}}=r_{B}$, the commercial bank that is chosen by the entrepreneur earns a zero expected profit (case 1 in figure 2). If, on the other hand, $\underline{r}_{B}>r_{B}$, competition between the two universal banks does not dissipate the entire profit since the entrepreneur prefers a repayment rate strictly larger than $r_{B}$ (case 2 in figure 2). Then, each commercial bank has a probability 0.5 of being chosen by the entrepreneur and earns an expected profit $0.5\left[\Pi_{C B}\left(r_{B}\right)+\Pi_{I B}\left(r_{B}\right)\right]>0$. We summarize in lemma 5 .

Lemma 5: In the presence of two universal banks, $\mathrm{CB} 1$ and $\mathrm{CB} 2$, each bank makes a bundled offer of commercial and investment banking services with an equilibrium repayment rate $\underline{r_{B}}=\max \left\{r_{B}, r_{B}\right\}$ in project $X$. Each bank has a equal probability 0.5 of being chosen by the entrepreneur and has an equilibrium expected profit of $0.5\left[\Pi_{C B}\left(\underline{r_{B}}\right)+\Pi_{I B}\left(\underline{r_{B}}\right)\right]$, which is zero if $\underline{r_{B}}=r_{B}=r_{B}$ and strictly positive if $\underline{r_{B}}=r_{B}>r_{B}$.

Proof: It directly follows from the discussion above.

According to the above discussion, the repayment rate in the loan that the entrepreneur takes to finance project $X$ is lower in a universal banking than in functionally separated banking system, i.e., $\underline{r}_{B}=\max \left\{r_{B}, r_{B}\right\}<\overline{r_{B}}$. Then, lemma 2 also implies that the underwriting fee in project $Y$ is lower under a universal banking than under a functionally separated banking regime, i.e., $\mu\left(\underline{r_{B}}\right)<\mu\left(\overline{r_{B}}\right){ }^{31}$

\subsection{Equilibrium Banking Structure}

We now examine the merger incentives of financial institutions when the formation of universal banks is legal (as, for example, in the U.S. after the Glass-Steagall Act was repealed and replaced by the Gramm-Leach-Bliley Act in 1999); CBi and IBi, 
$i \in\{1,2\}$, can make an endogenous decision about whether to merge. We can see that in equilibrium investment banks and commercial banks decide to merge to take full advantage of the opportunity to use commercial banking services to cross-subsidize underwriting activities. However, the endogenous decision of commercial and investment banks to merge has a prisoner's dilemma aspect; a universal banking system leads to lower profits for financial institutions than a functionally separated banking system where the formation of universal banks is illegal $\left(0.5\left[\Pi_{C B}\left(\underline{r_{B}}\right)+\Pi_{I B}\left(\underline{r_{B}}\right)\right]<0.5 \Pi_{I B}\left(\overline{r_{B}}\right)\right)$. The ability of universal banks to use commercial banking to cross-subsidize underwriting activities intensifies competition and erodes, partly if $r_{B}=r_{B}>r_{B}$, or completely if $\underline{r}_{B}=r_{B}=r_{B}$, - the supra-normal profits in the investment banking sector. Proposition 1 follows.

Proposition 1: In equilibrium CB1 merges with IB1 and CB2 merges with IB2. The equilibrium profits of financial institutions are strictly lower than in a functionally separated banking system.

Proof: The proof is in the appendix.

The ability of universal banks to cross-subsidize underwriting activities from commercial banking leads to a lower equilibrium repayment rate for project $X\left(\underline{r_{B}}<\overline{r_{B}}\right)$. Thus there is a reduced equilibrium level of monitoring in a universal banking system $\left(d \theta\left(r_{B}\right) / d r_{B}>0\right.$ according to condition (2)); commercial banks have a weaker incentive to monitor entrepreneurs since they expect a lower repayment rate on their investment in project $X$. Compared with a functionally separated banking system, there is a higher probability $1-\theta$ of an entrepreneur obtaining private rents; thus worse corporate governance is observed in entrepreneurial enterprises. Furthermore, the reduced underwriting fee in a universal banking system $\left(d \mu\left(r_{B}\right) / d r_{B}>0\right.$ according to lemma 2)

\footnotetext{
${ }^{31}$ This is consistent with the empirical findings of Drucker and Puri (2005) that the joint provision of commercial and investment banking services leads to lower underwriting fees and discounted commercial loan yields.
} 
leads to a lower probability $\alpha(\mu)$ of a successful public offering for project $Y$ (condition (3)). We summarize in proposition 2.

Proposition 2: (i) The equilibrium level of monitoring by commercial banks is strictly lower in a universal banking system $\left(\theta\left(\underline{r_{B}}\right)<\theta\left(\overline{r_{B}}\right)\right)$ while the probability of an entrepreneur obtaining private rents is strictly higher $\left(1-\theta\left(\underline{r_{B}}\right)>1-\theta\left(\overline{r_{B}}\right)\right)$.

(ii) The equilibrium probability of a successful public offering for project $Y$ is strictly lower in a universal banking system $\left(\alpha\left(\mu\left(\underline{r_{B}}\right)\right)<\alpha\left(\mu\left(\overline{r_{B}}\right)\right)\right)$.

Proof: It directly follows from the discussion above.

Social welfare, $\operatorname{TS}\left(r_{B}\right)$, is the sum of expected payoffs of all the agents, i.e., of the entrepreneur, the two commercial banks and the two investment banks. Thus social welfare, or total surplus, is $T S\left(r_{B}\right)=\Pi_{E}\left(r_{B}\right)+\Pi_{C B}\left(r_{B}\right)+\Pi_{I B}\left(r_{B}\right) .^{32}$ For simplicity, we assume that $T S\left(r_{B}\right)$ is strictly concave on $\left[\underline{r_{B}}, \overline{r_{B}}\right] .{ }^{33}$ Then, the legalization of universal banking unambiguously decreases social welfare when $T S^{\prime}\left(\overline{r_{B}}\right) \geq 0$, i.e., when $V_{X} \leq \gamma\left(x-\overline{r_{B}}\right)+\alpha\left(\mu\left(\overline{r_{B}}\right)\right)\left[\lambda y-V_{Y}+\mu^{\prime}\left(\theta\left(\overline{r_{B}}\right)\right)\right]$. It unambiguously increases social welfare when $T S^{\prime}\left(\underline{r_{B}}\right) \leq 0$, i.e., when $V_{X} \geq \gamma\left(x-\underline{r_{B}}\right)+\alpha\left(\mu\left(\underline{r_{B}}\right)\right)\left[\lambda y-V_{Y}+\mu^{\prime}\left(\theta\left(\underline{r_{B}}\right)\right)\right]$. If neither of these inequalities holds, the effects on social welfare are ambiguous. Proposition 3 follows.

Proposition 3: The legalization of universal banking unambiguously decreases social welfare if $V_{X} \leq \gamma\left(x-\overline{r_{B}}\right)+\alpha\left(\mu\left(\overline{r_{B}}\right)\right)\left[\lambda y-V_{Y}+\mu^{\prime}\left(\theta\left(\overline{r_{B}}\right)\right)\right]$ and unambiguously increases social welfare if $V_{X} \geq \gamma\left(x-\underline{r_{B}}\right)+\alpha\left(\mu\left(\underline{r_{B}}\right)\right)\left[\lambda y-V_{Y}+\mu^{\prime}\left(\theta\left(\underline{r_{B}}\right)\right)\right]$. In all other cases, the effects on social welfare are ambiguous.

\footnotetext{
${ }^{32}$ Competitive outside investors in project $Y$ always earn a zero expected payoff.
} 
Proof: The proof is in the appendix.

The effects of universal banking on social welfare stem from the reduction in the equilibrium level of monitoring $\left(\theta\left(\underline{r_{B}}\right)<\theta\left(\overline{r_{B}}\right)\right)$; all the other changes only constitute zero-sum transfers between the various agents. In general, the equilibrium levels of monitoring in the game are not necessarily socially optimal. At stage 1 competition between commercial banks in $r_{B}$ (which shapes the expected level, $\theta\left(r_{B}\right)$, of monitoring) aims to capture the entrepreneur and does not consider the positive effects of expected monitoring on the payoffs of financial institutions (commercial and investment banks); this may lead to a socially inadequate level of monitoring. On the other hand, a commercial bank's private decision about the level monitoring at stage 3 does not consider the entrepreneur's benefits from rent-seeking. Then, at stage 1 competition between commercial banks in $r_{B}$ often leads to a corner solution in which the expected level of monitoring is not as low as the entrepreneur would prefer, which may lead to a socially excessive level of monitoring. ${ }^{34}$

If the equilibrium level of monitoring in a functionally separated system is socially insufficient on a local scale $\left(V_{X} \leq \gamma\left(x-\overline{r_{B}}\right)+\alpha\left(\mu\left(\overline{r_{B}}\right)\right)\left[\lambda y-V_{Y}+\mu^{\prime}\left(\theta\left(\overline{r_{B}}\right)\right)\right]\right)$, the further reduction in monitoring that is brought about by universal banking is socially detrimental; universal banking is unambiguously welfare-decreasing. If, on the other hand, the equilibrium level of monitoring in a universal banking system is socially excessive on a local scale $\left(V_{X} \geq \gamma\left(x-\underline{r_{B}}\right)+\alpha\left(\mu\left(\underline{r_{B}}\right)\right)\left[\lambda y-V_{Y}+\mu^{\prime}\left(\theta\left(\underline{r_{B}}\right)\right)\right]\right)$, the further increase in monitoring that is brought about by functionally separated banking is socially detrimental; the universal banking system is unambiguously welfare-increasing. If neither inequality holds, the social welfare effects of universal banking are ambiguous.

\footnotetext{
${ }^{33}$ Our results are similar even if $T S\left(r_{B}\right)$ is not concave as long as the change in the equilibrium level of $r_{B}$ that is caused by universal banking is rather small, i.e., as long as $r_{B}$ is relatively close to $\overline{r_{B}}$.

${ }^{34} \mathrm{We}$ always have a corner solution $\left(r_{B}=\overline{r_{B}}\right)$ under a functionally separated regime (condition (6)). If $\underline{r_{B}}=r_{B}$, we also have a corner solution under a universal banking regime.
} 


\section{CONCLUSIONS}

The paper presents an industrial organization model to formalize the popular idea that financial conglomerates may make bundled offers of financial services, using commercial loans as loss leaders to obtain lucrative investment banking business. By focusing on the monitoring role of commercial banks, we also examine the impact of universal banking on social welfare and market structure. In our model there are supranormal profits in the investment banking sector that cannot be eroded by competition due to incentive problems with underwriting; when underwriting fees are too low, investment banks exert an insufficient effort. Universal banking serves as a mechanism for competing for such investment banking profits through cross-subsidization from commercial banking. However, the resulting commercial loan terms, which are favorable to customers and unfavorable to commercial banks, have an adverse effect on commercial banks' monitoring incentives, encouraging the pursuit of private rents by entrepreneurs. Less equilibrium monitoring also leads to lower underwriting fees and a lower probability of successful underwriting.

The social welfare effects of universal banking stem from the change in the level of monitoring. If the equilibrium level of monitoring in a functionally separated system is socially insufficient on a local scale, the universal banking system is unambiguously welfare-reducing because it exacerbates the inadequacy of monitoring. If, on the other hand, the equilibrium level of monitoring in a universal banking system is socially excessive on a local scale, the universal banking system is unambiguously welfareincreasing because it eases the excess of monitoring. Otherwise, universal banking has ambiguous social welfare effects. 


\section{REFERENCES}

Akerlof, George A., and Lawrence F. Katz. "Do Deferred Wages Eliminate the Need for Involuntary Unemployment as a Worker Discipline Device?" in Y. Weiss and G. Fishelson (eds.), Advances in the Theory and Measurement of Unemployment, London: MacMillan, 1990, p. 172-203.

Anand, Bharat N., and Alexander Galetovic. "Relationships, Competition, and the Structure of Investment Banking Markets," Journal of Industrial Economics, 54, December 2006, p. 151-199.

Association for Financial Professionals. Credit Access Survey: Linking Corporate Credit to the Awarding of Other Financial Services, 2004.

Barros, Pita P. "Multimarket Competition in Banking, with an Example from the Portuguese Market," International Journal of Industrial Organization, April 1999, 17, p. 335-352.

Beckett, Paul, and Jathon Sapsford. "Why J.P. Morgan Keeps Showing Up in the Wrong Place," Wall Street Journal, March 14, 2002.

Benston, G. The Separation of Commercial and Investment Banking, Oxford: Oxford University Press, 1990.

Besanko, David, and George Kanatas. "Credit Market Equilibrium with Bank Monitoring and Moral Hazard,” Review of Financial Studies, 6, 1993, pp. 213-232.

Boot, Arnoud W.A., and Anjan V. Thakor. "Banking Scope and Financial Innovation," Review of Financial Studies, 10, Winter 1997, pp. 1099-1131.

Brealey, Richard A., and Stewart C. Myers. Principles of Corporate Finance, 7th Edition, New York: McGraw Hill Irwin, 2003.

Diamond, Douglas. "Financial Intermediation and Delegated Monitoring," Review of Economic Studies, 51, 1984, 393-414.

Diamond, Douglas. "Monitoring and Reputation: The Choice between Bank Loans and Directly Placed Debt," Journal of Political Economy, 99, 1991, pp. 689-721.

Drucker, Steven, and Manju Puri. "On the Benefits of Concurrent Lending and Underwriting," Journal of Finance, 60, December 2005, p. 2763-2799.

Duffie, Darrell. "The Failure Mechanics of Dealer Banks," Journal of Economic Perspectives, 24, Winter 2010, p. 51-72.

Duffie, Darrell. How Big Banks Fail, Princeton, NJ: Princeton University Press, 2011. 
Economist. "Thanks a Bundle,” August 24, 2002.

Fama, Eugene F. "What's Different about Banks?" Journal of Monetary Economics, 15, 1985, pp. 29-39.

Freixas, Xavier, and Jean-Charles Rochet. Microeconomics of Banking, $2^{\text {nd }}$ Edition, Cambridge, MA: MIT Press, 2008.

Gächter, Simon, and Ernst Fehr. "Fairness in the Labor Market: A Survey of Experimental Results," in F. Bolle and Marco Lehmann-Waffenschmidt (eds.), Surveys in Experimental Economics, Berlin: Springer Verlag Berlin Heidelberg, 2002, p. 96-132.

Greenbaum, Stuart I., George Kanatas, and Itzhak Venezia. "Equilibrium Loan Pricing Under the Bank-Client Relationship," Journal of Banking and Finance, 13, May 1989, p. 221-235.

Hayes, S. and M. Spence. Competition in the Investment Banking Industry, Harvard University Press, Cambridge, MA., 1983.

Holmstrom, Bengt, and Jean Tirole. "Financial Intermediation, Loanable Funds, and the Real Sector," Quarterly Journal of Economics, 112, August 1997, p. 663-691.

Johnson, Simon and James Kwak. 13 Bankers: The Wall Street Takeover and the Next Financial Meltdown, New York: Pantheon Books, 2010.

Kanatas, George, and Jianping Qi. "Underwriting by Commercial Banks: Incentive Conflicts, Scope Economies, and Project Quality," Journal of Money, Credit, and Banking, 30, February 1998, pp. 119-133.

Kanatas, George, and Jianping Qi. "Integration of Lending and Underwriting: Implications of Scope Economies," Journal of Finance, June 2003, pp. 1167-1191.

Laux, Christian and Uwe Walz. "Cross-Selling Lending and Underwriting: Scope Economies and Incentives," Review of Finance, 13, April 2009, p. 341-367.

Loranth, Gyongyi, and Alan D. Morrison. "Tying in Universal Banks," Review of Finance, 16, April 2012, p. 481-516.

Marquez, Robert. "Competition, Adverse Selection, and Information Dispersion in the Banking Industry," Review of Financial Studies, 15, Summer 2002, p. 901-926.

Pugel, Thomas, and Lawrence White. "An Analysis of the Competitive Effects of Allowing Commercial Bank Affiliates to Underwrite Corporate Securites," in I. Walter (ed); Deregulating Wall Street: Commercial Bank Penetration of the Corporate Securities Market (John Wiley and Sons, New York), 1985. 
Puri, Manju. "Commercial Banks as Underwriters: Implications for the Going Public Process," Journal of Financial Economics, 54, 1999, pp. 133-163.

Rajan, Raghuram G. 'Insiders and Outsiders: The Choice between Informed and Arm'sLength Debt," Journal of Finance, 47, September 1992, p. 1367-1400.

Rajan, Raghuram G. "The Entry of Commercial Banks into the Securities Business: A Selective Survey of Theories and Evidence," in A. Saunders and I. Walter (eds), Universal Banking: Financial System Design Reconsidered, Chicago: Irwin Professional Publishing, 1996, p. 282-302. 


\section{APPENDIX}

\section{Proof of Lemma 2}

By totally differentiating first-order condition (5) we have

$$
\frac{d \mu\left(r_{B}\right)}{d r_{B}}=-\frac{\alpha^{\prime}\left(\mu\left(r_{B}\right)\right)\left(\lambda y-V_{Y}\right)}{[\sec \text { ond }- \text { order }- \text { condition }]} \frac{d \theta\left(r_{B}\right)}{d r_{B}}>0 .
$$

Furthermore, applying the envelope theorem to condition (3) leads to

$$
\frac{d \Pi_{I B}\left(r_{B}\right)}{d r_{B}}=\alpha\left(\mu\left(r_{B}\right)\right) \frac{d \mu\left(r_{B}\right)}{d r_{B}}>0 .
$$

Applying the envelope theorem to condition (4) implies that

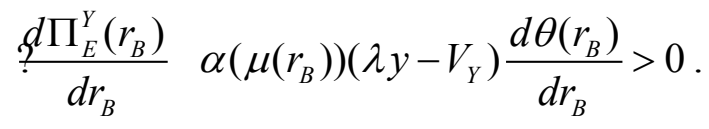

\section{Proof of Proposition 1}

As the payoff table below demonstrates, if CB1 and IB1 are independent entities, CB2 and IB2 will decide to merge since $\Pi_{I B}\left(\overline{r_{B}}\right)>0.5 \Pi_{I B}\left(\overline{r_{B}}\right)$. Furthermore, if CB1 and IB1 constitute a universal bank, $\mathrm{CB} 2$ and IB2 will also decide to merge since $0.5\left[\Pi_{C B}\left(\underline{r_{B}}\right)+\Pi_{I B}\left(\underline{r_{B}}\right)\right] \geq 0$. Thus $\mathrm{CB} 2$ and IB2 will always merge. Similarly for CB1 and IB1.

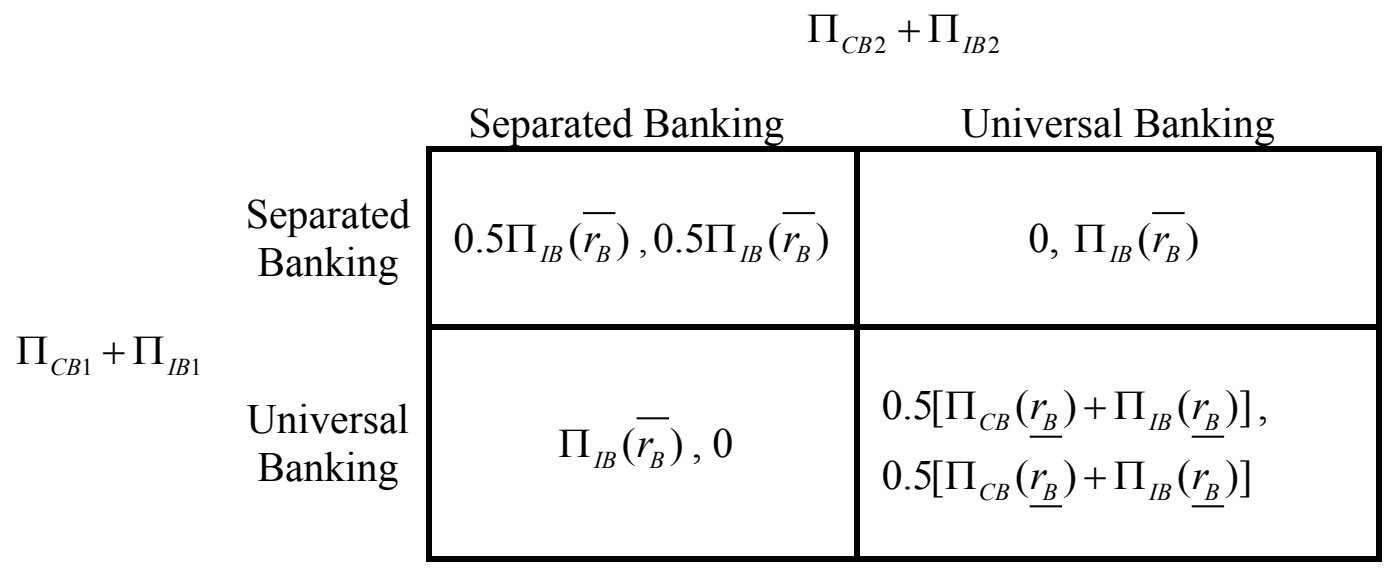

We have $\underline{r_{B}}<\overline{r_{B}}$ (lemma 5) and $d\left[\Pi_{C B}\left(r_{B}\right)+\Pi_{I B}\left(r_{B}\right)\right] / d r_{B}>0$ (note 23, expression (A2)). Thus a universal banking system leads to lower expected profits for financial 
institutions than a functionally separated banking system since $0.5\left[\Pi_{C B}\left(\underline{r_{B}}\right)+\Pi_{I B}\left(\underline{r_{B}}\right)\right]<0.5 \Pi_{I B}\left(\overline{r_{B}}\right)$.

\section{Proof of Proposition 3}

We know that $\Pi_{E}\left(r_{B}\right)=\theta\left(r_{B}\right) \gamma\left(x-r_{B}\right)+\left[1-\theta\left(r_{B}\right)\right] V_{X}+\Pi_{E}^{Y}\left(r_{B}\right)$, which implies that $\Pi_{E}{ }^{\prime}\left(r_{B}\right)=\theta^{\prime}\left(r_{B}\right) \gamma\left(x-r_{B}-V_{X}\right)-\theta\left(r_{B}\right) \gamma+\Pi_{E}^{Y}{ }^{\prime}\left(r_{B}\right)$. Incorporating condition (A3), we have $\Pi_{E}{ }^{\prime}\left(r_{B}\right)=\theta^{\prime}\left(r_{B}\right) \gamma\left(x-r_{B}-V_{X}\right)-\theta\left(r_{B}\right) \gamma+\theta^{\prime}\left(r_{B}\right) \alpha\left(\mu\left(r_{B}\right)\right)\left(\lambda y-V_{Y}\right)$. Furthermore, applying the envelope theorem to condition (1) gives $\Pi_{C B}{ }^{\prime}\left(r_{B}\right)=\theta\left(r_{B}\right) \gamma$ while condition (A2) gives $\Pi_{I B}{ }^{\prime}\left(r_{B}\right)=\alpha\left(\mu\left(r_{B}\right)\right) \mu^{\prime}\left(r_{B}\right) . \quad$ It follows that $T S^{\prime}\left(r_{B}\right)=\theta^{\prime}\left(r_{B}\right)\left\{\gamma\left(x-r_{B}-V_{X}\right)+\alpha\left(\mu\left(r_{B}\right)\right)\left[\lambda y-V_{Y}+\mu^{\prime}\left(\theta\left(\overline{r_{B}}\right)\right)\right]\right\}$.

If $V_{X} \leq \gamma\left(x-\overline{r_{B}}\right)+\alpha\left(\mu\left(\overline{r_{B}}\right)\right)\left[\lambda y-V_{Y}+\mu^{\prime}\left(\theta\left(\overline{r_{B}}\right)\right)\right]$, we have $T S^{\prime}\left(\overline{r_{B}}\right) \geq 0$. Given the strict concavity of $T S\left(r_{B}\right)$ on $\left[\underline{r_{B}}, \overline{r_{B}}\right]$, we have $T S^{\prime}\left(r_{B}\right)>0, \forall r_{B} \in\left[\underline{r_{B}}, \overline{r_{B}}\right)$, which implies that $\operatorname{TS}\left(\overline{r_{B}}\right)>T S\left(\underline{r_{B}}\right)$. Similarly, if $V_{X} \geq \gamma\left(x-\underline{r_{B}}\right)+\alpha\left(\mu\left(\underline{r_{B}}\right)\right)\left[\lambda y-V_{Y}+\mu^{\prime}\left(\theta\left(\underline{r_{B}}\right)\right)\right]$, we have $T S^{\prime}\left(\underline{r_{B}}\right) \leq 0$. Given the strict concavity of $T S\left(r_{B}\right)$ on $\left[\underline{r_{B}}, \overline{r_{B}}\right]$, we have $T S^{\prime}\left(r_{B}\right)<0$, $\forall r_{B} \in\left(\underline{r_{B}}, \overline{r_{B}}\right]$, which implies that $\operatorname{TS}\left(\overline{r_{B}}\right)<T S\left(\underline{r_{B}}\right)$. If neither of these inequalities holds, the effects of universal banking on social welfare are ambiguous. 